\title{
BEYOND CAPITAL FUNDAMENTALISM: \\ HARROD, DOMAR AND THE HISTORY OF \\ DEVELOPMENT ECONOMICS
}

by

MAURO BOIANOVSKY

CHOPE WORKING PAPER NO. 2015-12

OCTOBER 2015

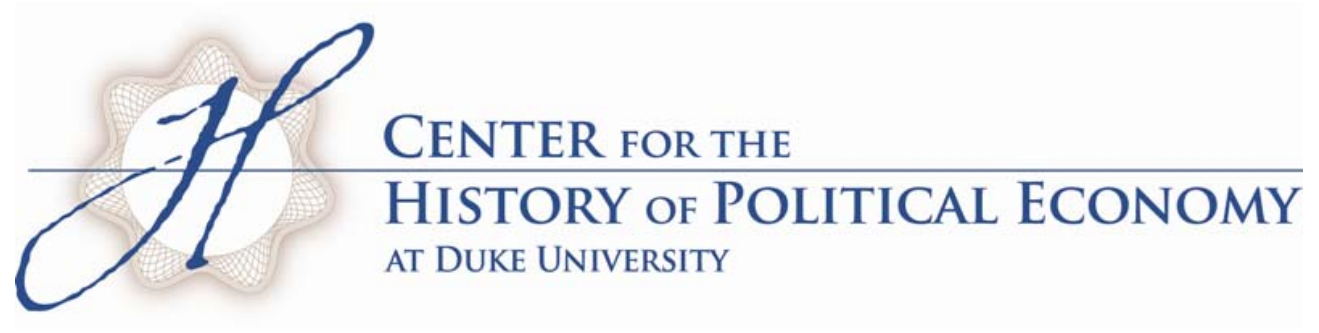




\title{
Beyond capital fundamentalism: Harrod, Domar and the history of development economics
}

\author{
Mauro Boianovsky (Universidade de Brasilia) \\ mboianovsky@gmail.com
}

Forthcoming, Cambridge Journal of Economics, 2018

\begin{abstract}
The origins of "capital fundamentalism" - the notion that physical capital accumulation is the primary determinant of economic growth - have been often ascribed to Harrod's and Domar's proposition that the rate of growth is the product of the saving rate and of the output-capital ratio. However, neither Harrod nor Domar fit in the "capital fundamentalism" idea. Development planners in the 1950s adapted the growth formula to their own agenda. Most development economists at the time were aware that Harrod's and Domar's growth models addressed economic instability issues, not long-run growth. Harrod eventually applied his concept of the natural growth rate to economic development. He claimed that the growth of developing economies was determined by their ability to implement technical progress. Domar observed that the incremental capital-output ratio was more likely a passive result of the interaction between the propensity to save and technological progress, not a causal factor.
\end{abstract}

Key words. Capital fundamentalism, Harrod, Domar, development economics, saving

JEL classification. B22, B31, O10 
Whether we could profitably invest a larger fraction of our national income is a controversial subject among economists. Much of course depends on the concomitant growth of the labor force and on technological progress. Without these two, and particularly the latter, the output contributed by an extra dollar of capital will decline with time. (Domar 1957c)

If an attempt were made to get growth in output per head merely by increasing the capital/labor ratio, when no other factors of increase were operating, it is likely that one would run into sharply diminishing returns, and very soon a nil return, from any further rise in the capital/labor ratio. (Harrod 1966)

\section{1. "Capital fundamentalism is wrong"}

That is the title of chapter 15 of Deirdre McCloskey's (2010) Bourgeois dignity, who borrowed the expression from William Easterly (2001, p. 48). The notion of "capital fundamentalism" became well known after Easterly $(1999,2001)$ turned it into the main target of his critical assessment of foreign aid policy, following an early study by Robert King \& Ross Levine (1994) about capital and growth. Pan Yotopoulos \& Jeffrey Nugent (1976, p. 12) introduced the term as one of the "fundamentalist dogmas" that, as they claimed, had beset development economics since its start as a new field in the 1950s. According to Yotopoulos \& Nugent, development economists had tended toward two methodological poles - introspective generalization and immanent criticism - which made the field replete with "dogmas" but lacking in operational theories (other listed dogmas included industrial, import-substitution and planning fundamentalisms). "Capital fundamentalism" described the monist preoccupation with physical capital accumulation as the primary determinant of the rate of economic growth. It reflected the "abortive crossing of introspective generalization with immanent criticism", which resulted from a direct transference of approaches designed for developed countries with slight changes to fit the peculiarities of developing economies.

As pointed out by Yotopoulos \& Nugent (ibid), the theoretical cornerstone of capital fundamentalism was the "Harrod-Domar model" proposition that the rate of 
economic growth $g$ is the quotient of the saving rate $s$ and the capital-output ratio $v: g$ $=s / v$ (see section 2 below). The return of capital fundamentalism and the HarrodDomar growth model as topics of discussion in the 1990s was largely motivated by the advance of endogenous growth theory, particularly under the guise of the socalled $A K$ models and their challenge to the Solow-Swan neoclassical growth model with diminishing returns to capital (King \& Levine 1994; Easterly 2001, chapters 2 and 3; Ray 1998, chapters 3 and 4; Barro \& Sala-i-Martin 1995, pp. 46-49; Aghion \& Howitt 1998, pp. 24-29; Harcourt 2006a, chapter 7).

Yotopoulos \& Nugent (ibid) did not cite passages from Roy Harrod (1939, 1948) or Evsey Domar ([1946, 1947] 1957a) to support their claim. Indeed, they absolved Harrod and Domar from the "capital fundamentalism" sin and suggested instead that its influence in less developed countries was based upon an "excessively mechanical interpretation" of the Harrod-Domar model, but did not elaborate further. They referred to Ragnar Nurkse (1953) and the United Nations (1960) as examples of recommended sets of growth policies that embodied the principles of capital fundamentalism. In the same vein, King \& Levine (1994, pp. 4-6) and Easterly (2001, pp. 28-30), despite assigning the origins of capital fundamentalism to the HarrodDomar growth equation, did not quote from Harrod or Domar but from W. Arthur Lewis's (1954, p. 155) well-known statement that an increase in the saving and investment ratio is the "central fact" of development, as well as from W.W. Rostow's (1956, p. 34; 1960, p. 41) similar description of the "take-off”. McCloskey's (2010, pp. 136, 139) too cited passages from Lewis and Rostow in her criticism of capital fundamentalism, but not from Harrod or Domar.

As discussed in the present paper, the absence of textual evidence that Harrod $(1939,1948)$ or Domar ([1946], [1947] 1957a) endorsed what has become known as the "capital fundamentalism" dogma reflects the fact that the proposition was not really part of their growth theoretical frameworks. This has been noted by some attentive readers, like Robert Solow (1999, p. 641): "The Harrod-Domar model tempted many - though not its authors - to the mechanical belief that a doubling of the saving-investment quota would double the long-term growth rate of a developing or developed economy". Harrod and Domar formulated the growth problem in the context of Keynesian macroeconomics. They shared a demand approach to economic growth, dominated by the investigation of the conditions under which the economy is able to bring about sufficient aggregate demand to allow for persistent expansion. 
Capital accumulation was perceived as a possible inhibitor of growth and generator of economic fluctuations. The issue is also relevant in the context of the ongoing controversy on demand-led growth between neo-Kaleckian and Sraffian economists (see Cesaratto 2015). Moreover, even if saving were matched by investment demand (e.g. in planned economies), there remained the matter of diminishing returns to capital, according to both Domar and (particularly) Harrod (see sections 2 and 5 below).

Development economists writing in the 1950s, at the apex of the influence of the "Harrod-Domar model", were not oblivious to its main features, and, more often than not, rejected its straightforward application to the interpretation of economic development (see sections 3 and 4). Lewis (1954, pp. 139-40), for instance, criticized the Keynesian (multiplier) view that capital supply does not restrict economic expansion, and argued for a "classical" (Ricardian) approach instead. Development planners - especially after Hans Singer's ([1952] 1958) path-breaking article assumed away Harrod's distinction between actual, warranted and natural growth rates. They were aware that the use of the Harrod-Domar formula to calculate "capital requirements" to reach a target growth rate differed from the original texts, but, as discussed in section 3, they adjusted it to their own agenda. From that perspective, development economists formed an "interpretative community" (Fish 1980) that changed the way the "model" was understood and used.

Doubts about the usefulness of the Harrod-Domar equation for development planning started to come up in the mid 1960s, when development economists (e.g. Leibenstein 1966; Streeten 1968; Morgan 1969) questioned on empirical and logical grounds the assumption that the incremental capital-output ratio (ICOR) is an independent causal factor of economic growth (section 4). However, such criticism remained a minority view, which led Easterly $(1999,2001)$ to expand the statistical tests and reiterate the results obtained by Harvey Leibenstein and others. As documented in section 5, Domar $(1955 ; 1961)$ mentioned the causality issue in his empirical investigations of the behavior of the capital-output ratio over time in the American economy.

Harrod $(1960 ; 1963 \mathrm{a}, \mathrm{b})$ took an interest in economic development in the 1960 s, when he introduced the notion of "optimum saving" as the saving ratio corresponding to the "natural" growth rate decided by population dynamics and technical progress (Boianovsky 2017a). Domar's (1957b) main contribution to 
development economics was his restatement of the two-sector growth model originally put forward by Russian economic planner G.A. Fel'dman in 1928. Like Harrod (1960; 1963a), Domar (1957b) may be seen as an exercise in optimal capital accumulation and dynamic welfare economics (section 5). In contrast with Domar's 1940s articles on growth economics, and closer to 1950s development economics, Fel'dman's model assumed perfectly elastic labor supply and absence of effective demand problems in a planned economy. Both Harrod and Domar eventually pointed to the qualification of workers, not physical capital, as the main determinant of the growth pace of underdeveloped countries. This comes out more clearly in Harrod than in Domar, who lacked a well-defined concept of the natural growth rate. The present paper provides an investigation of how Harrod's and Domar's growth models were received, transformed, adapted and occasionally rejected by development economists in the 1950s and 1960s, as well by some prominent growth theorists like Joan Robinson, Solow and William Fellner. A key issue was the role of saving in the economic growth process, which is conspicuous throughout the whole discussion.

\section{Is saving a virtue?}

It is often suggested that the Harrod-Domar growth model restored thriftiness to the "place of honor" it held before Keynes (see e.g. Brems 1968, p. 427). Indeed, that is how development economists (Sen 1983, p. 750; Stern 1991, p. 124; Ray 1998, p. 55; Easterly 2001, p. 29) have generally interpreted the model. As put by Daniel Hamberg (1971, p. 141), it is ironic that the extension of Keynesian macroeconomics to the long run by Harrod and Domar and its reception by development economists led to saving's revival as a main determinant of growth (see also Cesaratto 1999, p. 775). However, a close reading of Harrod and Domar shows that, despite the deceiving simplicity of their growth equation(s), the relation between saving and economic growth is anything but straightforward.

As it is well-known, Harrod $(1939,1948)$ distinguished between the actual growth rate per unit of time $G=s / C$, the warranted rate $G_{w}=\mathrm{s} / C_{r}$, and the natural rate $G_{n}$, where $s$ is the fraction of income saved, $C$ is the accretion of capital divided by the increment of goods produced in the same unit of time, and $C_{r}$ is the 
requirement for new capital divided by the increment of output to sustain which new capital is required, that is, the required ("accelerator") capital coefficient, a concept Harrod had already used in his 1936 Trade Cycle. The definition of $C_{r}$ followed from the assumption that the capital/output ratio is constant because inventions are Harrodneutral and the rate of interest is given. The expression for the actual rate $G$ is a tautology based on the identity between ex-post investment and ex-post saving. The warranted rate, on the other hand, expresses the equilibrium of steady growth, in the sense that entrepreneurs are satisfied with their production and investment decisions, so that the market for goods is in equilibrium. Harrod $(1939$, p. 17) called it the "fundamental equation" of economic dynamics. $G_{n}$ is the sum of the rates of growth of population and (Harrod-neutral or labor-augmenting) technical progress. It represents the ceiling or full-employment output path.

Instead of the backward relation between a given rise in income and the induced amount of investment assumed by Harrod's accelerator, Domar ([1946] 1957a) focused on the forward one between investment and the resulting increase in capacity. Equilibrium over time requires that aggregate supply (productive capacity) and aggregate demand (determined by investment $I$ and the multiplier) change at the same pace: $\sigma I=\frac{d I}{d t} \frac{1}{\alpha}$, where $\sigma$ and $\alpha$ stand for the potential social productivity of investment and the marginal (= average) propensity to save, both assumed to be stable. This is Domar's ([1946] 1957a, p. 75) "fundamental equation". The stability of $\sigma$ reflected Domar's assumption about the existence of limits to capital deepening (see Boianovsky 2017b). The solution to the differential equation is given by $I=I_{0} e^{\alpha \sigma t}$. Since the marginal and average propensities to saving are assumed equal and constant, income must also grow at the rate $r=\alpha \sigma$ in equilibrium.

That is a formula for the required, not actual growth rate. In particular, the larger the saving propensity $\alpha$, the larger is the increase in income required to avoid excess capacity. In the same vein, a high $s$ in Harrod's equations means that the rate $G_{w}$ is high, because only with a high rate of growth there will be enough investment to absorb (through the accelerator mechanism) the available saving. Hence, in both Harrod's and Domar's frameworks a higher propensity to save is accompanied by a higher growth rate along the equilibrium path only, supposing it is achieved in the first place. Whether a high $s$ or $\alpha$ brings about a high actual growth rate is a different 
matter, pertaining to the stability properties of Harrod's and Domar's models (see also Hahn and Matthews 1964, p. 786). ${ }^{1}$

For a given (actual) growth rate of investment and income, a higher propensity to save brings about excess capacity and unemployment in Domar's model, where saving is usually treated as a "curse" (Domar (1957a, p. 9). As put by Domar ([1947] 1957a, p. 100), "in general, a high $\alpha$ presents a serious danger to the maintenance of full employment, because investment may fail to grow at the required high rate". A higher propensity to save was recommended if the economy featured excess demand and inflation, which Domar (p. 97) mentioned only briefly. Moreover, a higher capital-output ratio (in the form of capital-intensive technological progress) was conducive to greater economic growth, since it increased investment demand per unit of output, as Alvin Hansen (1941) had argued (Domar 1948a; [1948b] 1957a, p. 118).

Harrod (1948, pp. 17-19) tackled upfront the matter of the relation between saving and growth. He identified a "stark contradiction" between old classical economics, in which saving was a "virtue" and accumulation the "motive power", and the Keynesian doctrine that saving is always tending to "retard advance". Harrod's (p. 88) solution to the contradiction involved a comparison between his three growth rates. Apparently, $G_{w}>G_{n}$ should produce excess demand for labor and boom conditions, whereas the opposite condition $G_{w}<G_{n}$ should lead to unemployment and stagnation. Harrod (ibid) argued, however, that it is not the value of $G_{w}$ that matters, but disequilibrium departures of $G$ from $G_{w}$ and their influence on production decisions. If $G_{w}>G_{n}, G$ must be lower than $G_{w}$, since the average value of $G$ over time cannot surpass full-employment $G_{n}$. Hence, $G_{w}>G_{n}$ implies paradoxically that the economy will be prevailingly depressed, and vice-versa if $G_{w}<G_{n}$. Such a paradox, claimed Harrod, was central to the contrast between classical and Keynesian economics, which were seen as particular cases of his more general framework. "Saving is a virtue and beneficial so long as $G_{w}$ is below $G_{n}$ ", since by raising $G_{w}$ it

\footnotetext{
${ }^{1}$ Although Harrod's and Domar's approaches differ in important aspects, there is a formal equivalence between their equilibrium growth equations, based on the notion that both capital coefficients assume that new investment is "properly utilized" (Harrod 1959, p. 452). If Harrod's warranted rate $G_{w}=\mathrm{s} / C_{r}$ is really an equilibrium rate, his accelerator coefficient $C_{r}$ must be the technical incremental capital-output ratio, not just a behavioral coefficient (see Hamberg 1971, pp. 10-11).
} 
enables the economy to obtain full employment without inflation. On the other hand, if $G_{w}$ is above $G_{n}$, saving is a "force making for depression".

Harrod (1939, p. 31) commented on the widespread opinion that a high propensity to save should warrant a great increase in output, and the associated “extreme aversion to accept Mr. Keynes' view that excessive saving in the modern age is hostile to prosperity". According to Harrod, "the feeling is justified to the extent that higher propensity to save does, in fact, warrant a higher rate of growth". The problem is that the rate of growth which it warrants may exceed the rate made permanently possible by the increase of population and technical progress.

Harrod's contention did not make for easy interpretation. Joan Robinson (1949, p. 81) - in the first installment of a debate with Harrod about the proper interpretation of the latter's model that would last for more than two decades - put forward some implications of Harrod's discussion of the case $G_{w}<G_{n}$. She understood it as implying that the capital stock is growing more slowly than the labor force, with ensuing progressive increase in unemployment. This is not "Keynesian" unemployment caused by deficiency of effective demand, but "Marxian" unemployment resulting from scarcity of capital relative to the labor supply. Although "nothing is farther from his thought, Mr. Harrod has led us to Marx's theory of the reserve army of labor, which expands and contracts as the growth of population runs faster or slower than the rate of capital accumulation". Robinson (ibid) suggested that such analysis of deficient thriftiness applied to backward over-populated countries, as opposed to the Keynesian case of excessive thriftiness devised for industrialized economies (see also Robinson 1956, pp. 404-06; Hamberg 1956, pp. 163-66).

Interestingly enough, Solow's (1956, pp. 73-76) influential - if controversial interpretation of "Harrod-Domar" as a fixed proportions growth model has implications that are reminiscent of Robinson's point about Harrod's "reserve army". Whereas Harrod had maintained that the excess of the natural rate over the warranted rate is conducive to high employment and inflationary boom conditions, Solow argued that this is a condition for a labor surplus economy instead (see also Wan 1971, p. 14). Claiming that the production side of the Harrod-Domar model is described by a Leontief production function $Y=F(K, L)=\min (K / a, L / b)$, where $a$ and $b$ are constants, Solow expressed Harrod's case $G_{n}>G_{w}$ as $n>s / a$ where $n$ is the rate of population growth (assuming away technical progress). He showed that under 
those conditions the capital-labor ratio $k$ and income per-capita $y$ decrease continuously toward zero, accompanied by permanent and increasing unemployment.

As put by Solow (1970, p. 10), the economy in that situation "saves and invest so little that it fails to create enough new capital" to employ the annual increment to the labor force. The converse case $G_{w}>G_{n}$ or $n<s / a$ featured convergence to a steady state with stable capital-labor ratio and increasing excess capacity (Wan 1971, pp. 40-42; Barro \& Sala-i-Martin 1995, pp. 47-48). Solow's reformulation implies that an increase in the saving propensity will raise the rate of economic growth permanently only if $G_{n}>G_{w}$ and income per capita is falling, for in that case diminishing returns will not come about, as the faster growth of capital will be accompanied by even faster growth of labor (see also Aghion \& Howitt 1998, p. 25).

Robinson's (1949) and Solow's (1956) interpretations did not take into account the instability caused by discrepancies between the actual and warranted rates. They both portrayed it imprecisely as a "knife-edge" equilibrium (Kregel 1980; Besomi 2001; Halsmayer \& Hoover 2015). Harrod (1957a, p. 6) reaffirmed his view that if the warranted rate is below the natural rate "there will be a tendency to overfull employment, not unemployment". Under these circumstances, differently from Robinson's (1949) or Solow's (1956) reading, a higher saving propensity could play a role in preventing inflationary excess demand for labor, but would not affect the permanent rate of economic growth. Harrod's (1948) depiction of two distinct disequilibrium tendencies (stagnation and exhilaration) raised Sunkel's (1970, p. 268) objection that developing regions like Latin America featured both inflation and (structural) unemployment, a scenario discussed by Hamberg (1956, p. 162) and further elaborated by Kurihara (1959, esp. chapter 6). Such a Robinsonian outlook may be also found in Thirlwall (1987, pp. 20-21) and Harcourt (2006b, pp. 222-23), who have argued that $G_{n}>G_{w}$ describes the coexistence of inflation and unemployment in low saving countries.

Development economists at the time were often aware of the intricacies of Domar's and (particularly) Harrod's analyses. The first primers on development economics started to come out in the mid 1950s, before growth economists produced their own texbooks in the early 1970s (Boianovsky \& Hoover 2009a). A number of authors (e.g. Meier \& Baldwin 1957, chapter 5; Higgins 1959, chapter 6; Enke 1963, pp. 171-77) discussed in detail several aspects of Harrod's and Domar's contributions, 
including instability issues and differences between their respective approaches. Naturally, the "Harrod-Domar growth model" attracted as well the attention of economists from underdeveloped countries interested in development planning, particularly at the United Nations Economic Commission for Latin America (CEPAL), as illustrated by Osvaldo Sunkel's (1956) careful study of Domar's methodology and its Keynesian foundations, further elaborated in Sunkel (1970, chapter V.2). ${ }^{2}$

As noted by Sunkel (1956, p. 206), both Harrod's and Domar's goal was to find the equilibrium rate of growth that prevents cyclical fluctuations. The cyclical dimension is stronger in Harrod because of his use of the accelerator, whereas Domar was deemed closer to the economic development agenda because his use of the capital coefficient led him to pay more attention to capital accumulation and the production function. The observed difference between the (expectational) accelerator and the (technological) capital-output coefficient reflected mistakes made by entrepreneurs in their investment decisions and the waste of capital in respect to its social productivity (Sunkel 1956, p. 212). Despite his enthusiasm for Harrod's and Domar's models, Sunkel (1970, p. 246) observed that the economic reality they tried to explain was distinct from Latin American socio-economic context. The emphasis on formal modeling and the corresponding use of a single equation - the "Harrod-Domar model" - had led economists to downplay the aspects of reality the models attempted to illuminate, to stress their formal similarities and to hide their theoretical differences (ibid).

Gerald Meier \& Richard Baldwin's (1957) thorough presentation of Domar's model included the notion that, the larger the propensity to save, the larger must be the amount of investment if growth is to be maintained (p. 105). Domar's and Harrod's theoretical frameworks shared the seemingly paradoxical result that, if the actual rate of growth exceeds the required or warranted rate, the economy will in fact produce too little, and vice-versa. Domar's paradox - that, to eliminate idle capital, more capital should be built, and that, to avoid capital shortage, investment should be reduced - reflected the multiplier effect of investment on aggregate demand,

2 Development planning also played a key role in India at the time. However, P.C. Mahalanobis (1953, 1955) elaborated Indian multi-sector planning models independently of Harrod or Domar, possibly under the influence of Fel'dman's similar 1928 contribution (Little 1992, pp. 47-51; Streeten 1968, pp. 1978-81). 
according to Meier \& Baldwin. Benjamin Higgins (1959, chapter 6 on "Cumulative movement away from equilibrium: Harrod") restricted his discussion to Harrod's formulation, which he found "more fruitful when applied to underdeveloped areas" than Domar's similar analysis. Harrod's conclusion that saving is a "good thing" in an inflationary gap economy, and a "bad thing" in a deflationary gap one was hardly surprising (Higgins, pp. 157-58). After playing with Harrod's equations for the actual, warranted and natural rates under different assumptions about sources of exogenous changes that could start economic growth in hitherto stagnant underdeveloped economies, Higgins (pp. 165-66) concluded that Harrod's analysis was "too general" and that his fundamental equations were essentially tautologies that did not provide empirical or functional (causal) relations determining the magnitudes of the variables.

An important distinction between Harrod and Domar, pointed out by Stephen Enke (1963, p. 175), was that Harrod's warranted rate referred to a point in time, with no supposition that the values of $s$ and $C_{r}$ are constant parameters, in contrast with the assumed stability over time of Domar's $\alpha$ and $\sigma$. There can be steady growth in Harrod even if $s$ and $C_{r}$ vary over time, provided they change in the same proportion and direction. Neither did Harrod assume that the average propensity to save is equal to the marginal one. The use of Harrod's formula for economic projections was made difficult by the fact that there is no assurance that the rate of growth of output in the future will be equal to the past value of $s$ divided by the past value of $C_{r}$. Some development economists, noted Enke (ibid), treated the warranted growth rate as an identity "restated in a way that seems to imply that $s$ and $C_{r}$ are parameters". The relevant question was whether such ratios are ex post observations or ex ante guides. Although logically they are only the former, their use for extrapolation in order to calculate "capital requirements" was widespread at the time, as discussed next.

\section{Capital requirements and development planning}

Following their literature review, Meier \& Baldwin (chapter 16) and Higgins (chapter 27, pp. 642-53) discussed development planning techniques, broadly based on the calculation of capital requirements according to three steps: estimate of the likely rate of population growth, setting of a target for the desired rate of increase in per capita 
income, and application of some figure for the ICOR (Meier \& Baldwin, pp. 338-39). The resulting required saving rate provided an "instrument" variable for planning, as Jan Tinbergen (1958) called it. The complexity of Harrod's and Domar's analytical frameworks was gone, and instead a direct linear relation between saving and growth was assumed. Higgins (p. 642) made clear that the first question in development planning was "how much total investment is needed to produce target increases in per capita income?" Harrod and Domar were conspicuously absent from Higgins's discussion of development planning. Meier \& Baldwin (p. 339, n. 5) did mention that their method for measuring capital requirements was "an alternative" to Harrod's and Domar's. Whereas the Harrod-Domar approach assumed a given saving ratio and market determined growth, the method deployed by Meier \& Baldwin and other development economists was supposedly relevant for economies in which development is governmentally planned and the saving ratio becomes a policy variable (cf. Harrod's “optimum saving” concept, tackled in section 5 below).

That was a crucial distinction, as Robinson (1962, chapter 5) would point out. The misleadingly simple Harrod-Domar formula $g=s / v$ (where $v$ is the ICOR and $g$ the rate of growth of output) seemed to suggest that the rate of growth $g$ is determined by technical conditions and saving, not by effective demand. However, "greater thriftiness requires a higher rate of growth, but does not provide any motive for it", observed Robinson (1962, p. 100, n. 1). That changed if government took upon itself to direct economic development and investment was decided by a conscious plan, for propositions derived from the growth formula $g=s / v$ "then have something to say" (ibid, p. 110). Although Harrod and Domar originally had the business cycle problem in mind, the concept of capital-output ratios was "easily transferable" to growth problems in underdeveloped areas, as Leibenstein (1957, p. 176) argued while deriving the growth formula as a tautology. ${ }^{3}$

Albert Hirschman (1958, p. 29) saw the application of growth models (originally devised for advanced industrial countries) to the discussion of the economic development of backward economies as one of the "astounding feats of

${ }^{3}$ Leibenstein (p. 177, n. 1) wrote the identity $\frac{I}{Y} \cdot \frac{\Delta Y}{I}=\frac{\Delta Y}{Y}$, that is, the rate of investment times the inverse of the ICOR is equal to the rate of growth. This corresponds to Harrod's (1948, p. 80, n. 1) tautological expression for the actual growth rate, based on the ex post identity between saving and investment. See also Ray (1998, pp. 54-55, 90-91) for a similar derivation of the "Harrod-Domar equation". 
modern economics". The "Harrod-Domar analysis" had found its main field of application in the planning of development for underdeveloped countries. According to Hirschman (p. 31), this reflected the fact that the models had been designed to explain the possibility of secular stagnation in the postwar period, which that had not been confirmed. Instead, they were adapted and deployed in a completely different setting and for other purposes.

Hans Singer, an economist at the UN headquarters in New York and a former student of Keynes at Cambridge, carried out the first application of the Harrod-Domar equation to development planning. His article came out in India in 1952, with concomitant Spanish and Portuguese versions in Mexico (El Trimestre Económico) and Brazil (Revista Brasileira de Economia). It was reproduced in the first ever collection of readings in development economics, edited in 1958 by Indian economists A. Agarwala and S. Singh. When applying the Harrod-Domar "very simple, almost tautological" equation to the interpretation of the "mechanics of development", Singer ([1952] 1958, p. 396) made an important change in the original formula. He was interested in "economic development", defined as growth of per capita income as expressed by his equation $D=s p-r$, where $D, s, p$ and $r$ stand for growth per capita, saving ratio, productivity of new investment per unit of capital and the rate of population growth, respectively.

That was not just an innocent algebraic modification. It represented a curious mix of classical (Malthusian) and Keynesian insights. The Keynesian view of population growth in industrialized economies was that it stimulates the economy through its effect on the demand for investment ("capital widening"), as claimed by Keynes (1937) in an article that anticipated the core of Harrod's (1939) concepts of the warranted and natural rates of growth (see also Harrod 1955a). Hansen (1941) based his analysis of secular stagnation on the perverse effects of declining demographic growth (together with falling pace of capital-intensive technical progress) on investment, which Domar (1948a) incorporated into his framework. Singer ([1952] 1958, p. 399) deployed a distinct approach. He clarified that the fact that $r$ appears with a minus sign should not be interpreted as proof that population is an obstacle to economic development. He contemplated the possibility that a high $r$ may have an effect on $s$ and especially on $p$. The idea behind the formula, as Singer (1954) explained, was that increased population, while requiring capital for its productivity, would not in itself contribute to production and capital accumulation. 
Because of the assumption of a given exogenous capital-output ratio, that "static" formula disregarded the "dynamic" possibility that additional labor, even without additional capital, could yield significant (but not proportional) increases in output through induced innovation and factor substitution. ${ }^{4}$

Singer's comments about factor substitution were only side remarks, though. The formula was used by him - and by many others ever since - to calculate the resulting value of any of the four variables by assuming parametrical values for the other three. For instance, given the target rate of economic development $D$, and given $p$ and $r$, the equation provided the saving ratio $s$ necessary to support the stipulated rate of development (Singer [1952] 1958, pp. 396-98). Raul Prebisch (1954), executive secretary of CEPAL, used a version of Singer's formula with capital depreciation to calculate foreign capital inflow in order to reach a target growth rate in Latin America, with no references to Harrod or Domar. Tinbergen adopted a similar framework in his 1958 book and in the 1960 UN document prepared by a group of experts chaired by him. Tinbergen (1987, p. 134) would recall in an interview years later: "We followed what at the time was the most usual approach, namely to determine the needs for investments in order to attain a certain rate of development and then try to find out what [developing countries] could finance themselves and to finance the shortage by foreign aid. So that was the line of reasoning that was followed by people like Hans Singer..."

Despite his 1942 pioneer exercise in neoclassical growth modeling based on the Cobb-Douglas production function, Tinbergen assumed a given stable capitaloutput ratio in his contributions to development planning. Such long-run stability of the capital-output ratio (at a value around 3) was seen as based on solid empirical grounds, "one of the most useful parameters with a fair degree of stability" (United Nations 1960, p. 11). It was not interpreted as the steady-state result of factor substitution as in Solow's (1956) model, where income per capita and the capital-

\footnotetext{
4 The notion of a rigid capital-output ratio implies that only capital accumulation, not increased population, raises output. In the Solow-Swan growth model, on the other hand, under the assumption of a production function with factor substitution, the steady-state rate of per capita output growth is independent of the rate of saving (= rate of investment) and of the rate of population growth. According to the SolowSwan model, an increase of the rate of growth of population has no long-run effect on the growth of output per capita, but it reduces its level.

5 The stability of the capital-output ratio would soon be listed by Kaldor (1961) as one of the "stylized facts" about economic growth in the long run or steady state.
} 
labor ratio increase at the same rate (= rate of technical progress) in long-run equilibrium. Rather, it was tentatively explained by complementarities of industrial activities or by compensation of increases in the capital-coefficient in some sectors by decreases in others.

Tinbergen did discuss in passing the assumption that output is a linear function of capital only. In general, output should be treated as a function of capital and labor and the changing relation between them. To base the projection of national output on the (stable) capital-output ratio implied a "certain type of technical change in the relevant future". The notion - that the observed long-run stability of the capital coefficient resulted from the effect of technical progress offsetting diminishing returns to capital accumulation - was introduced by William Fellner (1951, p. 115) and endorsed by Domar ([1952] 1957a, pp. 26-27). Development economists (e.g. Hirschman 1958, p. 31; United Nations 1955, p. 23) referred often to US data, calculated by Fellner $(1951,1954)$ and others, as vindicating the assumption of a given capital-output ratio, and occasionally (e.g. Bruton 1955, pp. 326-27; Sunkel 1956, p. 211) repeated the Fellner-Domar argument about technical progress to interpret such stability. Hence, the steadiness of the capital coefficient was often regarded a feature of the time series, not of the production function itself.

Capital requirements were dealt with not just in the context of the development planning of poor countries, but also in discussions about economic growth of advanced economies. Indeed, Ernest Stern's (1945) examination of capital requirements in the US, UK and South Africa was the first exercise of that kind. It came out before Harrod (1948) and Domar (1946 and 1947), with no reference to Harrod (1939). Stern started from Carl Snyder's $(1936,1940)$ statistical work on the relation between capital and output in American industries. Snyder had interpreted his finding of proportionality between the rates of growth of output and capital as proof that the increase of the capital-labor ratio was the source of "national well-being". Using time series from S. Kuznets and other sources, Stern (p. 169) computed the "capital investment per unit of growth of national income" (that is, the ICOR) and used it to estimate capital requirements: "Multiplying it by the rate of growth provides a numerical expression of the annual capital requirements as \% of National Income, in other words, the required savings rate". This is not exactly the same as Singer's ([1952] 1958) target rate, since Stern used the observed growth rate as a basis for the projected one. 
Fellner (1954) carried out a similar but more detailed study about US economic growth in section 4 and other parts of his NBER report. Harrod's and Domar's contributions were now well-known and influential, but this did not make Fellner's approach significantly distinct from Stern's arithmetical insight. Fellner's (p. 284) formula for capital requirements, like Stern's, was based on the ex post identity between saving and investment (see also Fellner 1951). He claimed that such a tautological relation could provide useful information if it were possible to "appraise the conditions in which the values in question would tend to repeat themselves" in the future - this applied to long-run average values when all adjustments to changing conditions had been made.

Fellner did not make use of Harrod's analytical distinction between three growth rates. He was concerned with "observable long-run values involved in Harrod's $G C=s$ " and assumed that "these tend to be the warranted values at the same time" (Fellner 1954, p. 294). He, therefore, interpreted the long-run actual values as first approximations to the warranted values. Moreover, Fellner (ibid) assumed away the existence of a definite natural growth rate, on the grounds that the marginal capital-output ratio - which depends on production methods - may adjust in the long run. The "element of truth overstated" by Harrod's $G_{n}$ concept, argued Fellner, was that diminishing returns, caused by capital accumulation at a faster rate than population growth, might interrupt the economic growth process. Economic growth required that such a tendency should be counteracted in the long-run by technical progress induced by relative factor scarcity, as Fellner believed to be the case.

Development planners tended to share Fellner's approach of disregarding differences between the actual and warranted growth rates. ${ }^{6}$ They also often ignored Harrod's natural growth rate as long as unlimited supply of labor was assumed, as in the Marxian notion of the "reserve army" of the unemployed or Lewis's concept of perfectly elastic labor supply (Little 1982, p. 42; Marglin 1984, p. 108). The assumption of permanent "structural" excess supply of labor permeated CEPAL's reports about development planning. Planning techniques took as their starting point

\footnotetext{
${ }^{6}$ Hamberg (1971, p. 12) maintained that, since the Harrod model "only makes sense" if its accelerator behavioral coefficient is equal to the technical marginal capital coefficient, it is advisable to concentrate on its purely equilibrium aspects (as Fellner did). Hamberg believed that "failure to do so has led to a good deal of unnecessary confusion in the arena of public policy, especially in regard to the underdeveloped economies".
} 
Singer's ([1952] 1958) version of the Harrod-Domar formula, regarded as a "most valuable instrument for the analysis and programming of development" (United Nations 1955, p. 20; see also Boianovsky 2010, pp. 244-48). The production process illustrated by that equation focused upon one single factor (capital), but a closer look indicated that other factors like natural resources, technical progress and labor were taken into account through their (implicit) influence on the productivity of capital investment (United Nations 1955, p. 20; Sunkel 1956, p. 211). This echoed Domar's ([1947] 1957a, p. 90) original formulation of that concept, which he distinguished from the marginal productivity of capital.

The application of the Harrod-Domar framework to an open developing economy raised new questions, since a substantial part of the supply of capital goods was imported from abroad. CEPAL defined the "foreign exchange constraint" as the amount of exports upon which Latin American countries depended to transform their saving into imports of capital goods. The development bottleneck may consist of foreign exchange rather than domestic saving if the rate of growth allowed by exports is lower than the rate allowed by saving. As put in a report about the Brazilian economy drafted by Celso Furtado,

It is pertinent to consider a problem specific to under-developed countries namely, that of the possibility of transforming saving into real investment. It is well known that in a developed economy saving does not necessarily imply growth, since in this case it is the level of effective demand that conditions the process of accumulation. Similarly (but for other reasons), saving in an underdeveloped economy is not always an effective cause of growth. There must also be the possibility of converting this saving into real investment - a possibility dependent upon the capacity to import (United Nations 1956, p. 9).

CEPAL's analysis of the foreign exchange constraint marked the beginning of the two-gap approach to the balance of payments and growth. It also provided the starting-point of the so-called "Prebisch-Thirlwall law" that the relative rates of growth of developed and underdeveloped countries is determined by the quotient between the income-elasticity of the latter's imports from industrial countries and the income-elasticity of their exports, based on an extension of Harrod's 1933 foreign trade multiplier (Boianovsky \& Solís 2014). Chenery \& Bruno (1962) and Chenery $\&$ Strout (1966) would formalize the two-gap approach by means of nonlinear 
programming models. Such models investigated whether foreign capital inflows were needed to supplement domestic saving or purchase imported capital goods. Chenery \& Bruno (pp. 84-85) provide additional illustration of how Harrod's original framework was transformed and adapted to development planning. They acknowledged that Harrod $(1939,1948)$ was primarily concerned with cyclical fluctuations, but claimed that "his relations can be reinterpreted as a simple policy model of development alternatives" in which parameters are turned into policy variables. They saw their contribution as the addition of a third restriction to economic growth (apart from domestic saving and labor supply), represented by the balance of payments.

Chenery \& Strout (1966, p. 687) redefined Harrod's natural rate as a skilldetermined rate, that is, the rate of growth of skilled labor force, which was supposed to decide the ability of the economy to absorb capital productively. The concept of "absorptive capacity", put forward by development planners in the late 1950s and early 1960s, was based on the notion that the productivity of new investment depended on the supply of "cooperative factors" (natural resources, labor supply, technical skills etc.) that set a limit to the amount of efficient investment physically possible (Meier \& Baldwin 1957, pp. 351-55; United Nations 1960, p. 10; Rosenstein-Rodan 1961b, pp. 108-09; for a historical survey see Guillaumont 1971). Harrod's (1963b) notion of diminishing returns to capital accumulation had some similarities with that concept (section 5 below). However, differently from development planners, some economic development theorists came close to reject the Harrod-Domar model altogether, as documented in the following section.

\section{Development economists' criticism}

For different reasons, capital formation played an important role in the early years of development economics (Arndt 1987, pp. 54-60; Meier 2005, chapters 4 and 5). Despite their distinct approaches to economic development, Rosenstein-Rodan (1943, 1961a, b), Nurkse (1953), Lewis $(1954,1955)$ and Rostow (1952, 1956, 1960) shared an emphasis on capital accumulation. This has led commentators to infer that their various theoretical frameworks were influenced by or at least consistent with the “Harrod-Domar" model. Referring to Lewis's (1954) path-breaking analysis of dual 
economic development, Gollin (2014, p. 82) writes that "Lewis's thinking was heavily informed by the Harrod-Domar model". ${ }^{7}$ However, Lewis (1954, p. 140) stated at the outset that he offered his classical framework of growth in countries with surplus labor as an alternative to both Keynesian (where there is also surplus capital) and neoclassical (full employment) approaches. In the introduction to his 1955 volume Lewis (p. 13) mentioned recent "elegant work" about the mathematical stability of economic growth. Such models sought to establish how far the relationships between economic coefficients are consistent with stable growth, with no investigation of what decides their values and how they change over time. The theory of economic growth should instead address long-term changes in propensities, especially the saving ratio, as Lewis set out to do.

In his discussion of the Victorian view that saving is a virtue, Lewis (1955, p. 215) considered the opposite perspective that an increase in saving may discourage investment. This argument depended upon the notion that the ratio between aggregate capital and total consumption was fixed, since, if this was not the case, capital accumulation could proceed faster than the rate of growth of consumption. The assumption of a given or stable ratio between capital and output (or consumption) played an important role in Domar's assessment of the controversy about secular stagnation, which provided the starting-point for his own growth model (see Boianovsky 2017b). Lewis (1955, pp. 296-97) doubted there were such fixed ratios between capital, income and consumption, as capital-intensity depended on variables like the rate of interest. He, therefore, rejected the secular stagnation hypothesis based on rigid ratios. Neither did Lewis accept the application to labor surplus economies of the traditional view that capital accumulation brings about diminishing returns and falling rates of profit. Since there is labor available, "capital accumulation does not alter the ratio of capital to labor in employment, and so there is no tendency for the rate of profit to fall" (ibid). ${ }^{8}$ Unlimited capital widening was possible in labor surplus economies (Lewis 1954, p. 154).

7 Tignor (2006, p. 97) has also suggested that Lewis (1954) fit comfortably within the Keynesian Harrod-Domar growth theory.

8 This is a key analytical difference between Lewis's and Solow-Swan's models. As pointed out by Swan (1956), the positive permanent effect of a higher saving ratio on economic growth in Lewis's model - as opposed to Solow-Swan - is due to the assumption that the supply of labor is elastic in the vicinity of a certain level of output per capita. The growth of the productively employed labor force depends on the rate 
It is against that background that Lewis's (1955, pp. 201-13) section on "capital requirements" should be read. Lewis noted the "remarkable" stability of the observed value of the incremental capital-output ratio between 3 and 4 . From a mathematical perspective, the (average) ratio was a function of the rate of investment, the rate of growth of income and the average life of capital goods. ${ }^{9}$ Assuming, moreover, a typical value of the rate of investment between 4 and 5 per cent, the corresponding rate of growth is about $1.25 \%$, which corresponded to India's demographic growth. In order to increase India's income per capita at the same pace as the U.S. (between 1.5 and 2 per cent), it would be necessary to raise the rate of investment to about 12 per cent. According to Lewis (1955, p. 208), all developed countries had gone in the past through a period of growth acceleration when their rate of investment moved from $5 \%$ or less to $12 \%$ or more - an "Industrial Revolution".

That was behind Lewis's (1954, p. 155) oft-quoted statement that the "central problem of the theory of economic development" is to understand the process by which an economy modifies its rate of saving and investment from 4 or 5 per cent to 12 or 15 per cent. Lewis's model of economic growth in a dual economy with perfectly elastic labor supply was designed to show how the increase of the share of profits in income brings about changes in the rate of saving and investment. Harrod's $(1939,1948)$ and Domar's $(1946,1947)$ growth analyses are nowhere mentioned. ${ }^{10}$ Lewis's use of the so-called Harrod-Domar equation without attribution indicates that it had become common knowledge by the mid 1950s. More than that, he clearly distinguished that equation from Harrod's and Domar's Keynesian models of growth, as documented above. Lewis (1955, pp. 234-35) explained the growth of the capitalist sector and of the share of profits in income - and therefore of the saving ratio - as functions of the opportunities for investment. Labeling Lewis "capital fundamentalist" should therefore be done cum grano salis.

of capital accumulation, which gives Lewis's model its classical flavor. See also Marglin (1984, chapter 5) on the distinction between Harrod and Lewis.

${ }^{9}$ This corresponds closely to Domar's ([1946] 1957a) expression $\lim _{t \rightarrow \infty} \frac{K}{Y}=\frac{\alpha}{r}$, where $r$ is the rate of growth of output.

${ }^{10}$ Lewis $(1955$, p. 251$)$ referred to Domar only in connection with the latter's wellknown 1950 discussion of the effects of foreign investment on the balance of payments of a growing economy. That was also Nurkse's (1953, pp. 131-32) only mention of Domar. Likewise, Nurkse's (p. 125) only reference to Harrod was in connection with the relation between capital movements and trade (Harrod 1948, pp. 101-15). 
Lewis's (1954) concept of the dual economy with elastic labor supply may be found in post-Keynesian contributions made in the 1950s and 1960s by Kaldor, Kalecki and others to growth and development theories (see Kriesler 2013). PostKeynesian economists generally asserted that the specific problem of developing countries was shortage of capital to fully employ the labor force in the modern sector, instead of productive capacity underutilization characteristic of industrialized mature economies. Again, like Lewis, both Kaldor and Kalecki stressed low productivity of traditional agriculture as the ultimate factor behind the relatively slow pace of capital accumulation and growth in underdeveloped economies (see Boianovsky 2017c).

Indian economist V. Rao ([1952] 1958) - Singer's colleague at Cambridge in 1933-35 - argued that inelastic aggregate supply (particularly in the agricultural sector) prevented the application of the multiplier concept to India and other developing economies. Rao (p. 218) claimed that such countries should follow instead the classical old-fashioned prescription - which he did not associate with Harrod or Domar - to "save more". Similar criticism came from Latin America as part of Sunkel's (1957) detailed study of the Kahn-Keynes multiplier and its application to developing countries. The level of employment in such economies, featuring "disguised unemployment" with zero marginal productivity of labor, was seen as limited by the amount of capital, not by effective demand. Prebisch (1948) too was critical of the Keynesian multiplier and the notion that saving affects negatively the level of activity and the rate of growth. His criticism, however, based on a mix of Robertsonian and Austrian elements, was a more general criticism the multiplier concept (see also Pérez Caldentey and Vernengo 2016).

Rostow's (1956, pp. 32-33; 1960, p. 41) numerical characterization of the take-off as requiring "by definition and assumption" an increase of the rate of investment from about $5 \%$ to about $10 \%$ or more was taken directly from Lewis (1954, 1955). As he acknowledged, it was essentially a "tautological" definition. Again, just like Lewis, Rostow's deployment of the arithmetical relation between growth, saving and the capital-output ratio did not mean endorsement of Harrod's or Domar's growth models, which he clearly distinguished from the standard equation $g$ $=s / v$. Formal work on growth modeling, according to Rostow, was mainly concerned with the instability of industrialized economies in the third stage of their growth process, that is, after the take-off into sustained growth. Development economists, on the other hand, focused on the first two stages - the economics of the pre-conditions 
and the take-off. A "serious theory of growth" should investigate closely the economics of the take-off, something Harrod, Domar and their followers had not done (Rostow 1956, pp. 31-32). ${ }^{11}$

Rostow (1952, pp. 87-92) had discussed closely Harrod's (1948) approach to growth, with its formal statement of the conditions for steady advance and analysis of deviations from that path. He found Harrod's framework well suited for showing the inherent instability of a growing economy, but not for investigating the determination of the growth rate itself and its changes in the long run. That depended on what Rostow (1960, pp. 12-16) called a disaggregated "dynamic theory of production" based on the interaction between different sectors as technical progress diffused throughout the economy. As put in the second edition of his Stages book, "without the leading sectors the fundamental connection between growth and new technologies disappears into the mists of the Harrod-Domar equation and statistical aggregates of highly ambiguous meaning” (Rostow 1971, p. 188). Like Lewis, Rostow’s historical object was the Industrial Revolution.

Hirschman (1958, chapter 2) addressed upfront the ability of Harrod-Domar growth models to explain the development process. The success of Domar's simple model was measured by the fact that "we must pinch ourselves to remember that it is a theory rather than a faithful copy of reality", despite the fact that Domar limited himself to defining the rate of growth required for steady growth, independently of whether it is actually achieved or not (pp. 30, 34). That was related to the lack of a satisfactory theory of investment, the main defect of growth models in general. Moreover, Hirschman saw saving and investment decisions in developing countries as largely interdependent, in the sense that additions to saving are determined not so much by increased income but by new investment opportunities and the elimination of obstacles to investment. Harrod-Domar functional relations were useful in the limited domain of development planning, but, when deployed to interpret and explain the development process, the model turned into a "hindrance rather than a help in the understanding of the reality of underdeveloped countries" (p. 32).

11 "Although couched in the language of growth, the theoretical exercises of Harrod, Domar and others have not been concerned with the variables determining differences in the rate and structure of growth. Their primary purpose has been to demonstrate that the growth process is likely to proceed in unstable cycles of unemployment" (Rostow 1955, p. 637). 
Like Rostow, Hirschman criticized the way production decisions and their sectorial links were overlooked in Harrod-Domar formulations. The main element restricting economic development was the "ability to invest" - channeling existing or potentially existing saving into available investment opportunities - instead of the supply of saving per se. Hirschman's "ability to invest" was closely related to the notion of "absorptive capacity" (mentioned above in section 3), treated not as a deviation from the norm but as the standard case. It was in that context that Hirschman introduced his concept of unbalanced investment-stimulating projects through linkages brought about by complementarities and external economies effects. $^{12}$

Such effects also played an important role in Rosenstein-Rodan's and Nurkse's theories of development, but - instead of Hirschman's unbalanced growth strategy via market incentives created by disequilibrium itself - they argued for balanced growth implemented by a coordinated wave of capital investments in different sectors, called Big Push by Rosenstein-Rodan 1961a (Little 1982, chapter 3; Ray 1998, chapter 5). Their emphasis on capital accumulation is well illustrated by Nurkse's $(1953$, p. 142) remark that “the country's marginal propensity to save is the crucial determinant of growth". Nurkse (p. 148) contrasted that proposition with Keynes's ridicule of the Victorian virtues of thriftiness, regarded by Nurkse as "pernicious" when transplanted to underdeveloped countries.

Nurkse did not refer to Harrod-Domar growth models; neither did RosensteinRodan. This is hardly surprising, as indivisibilities and increasing returns - crucial to their interpretation of underdevelopment as a low-level equilibrium trap caused by a massive coordination failure - are not part of Harrod's or Domar's frameworks. Indeed, in an unpublished lecture Domar (1967), who was by then RosensteinRodan's colleague at MIT, thought it better to avoid modeling external economies, which he found "too difficult" and "exaggerated". Around that time, Kaldor's (1966) formulation of (what became known as) the "Kaldor-Verdoorn law" stressed the role of increasing returns in the formulation of models of economic growth and development. Again, that implied a movement away from the Harrod-Domar original

\footnotetext{
12 Harrod seemed to agree with Hirschman's argument. In correspondence of 1963 with Hirschman, Harrod praised Strategy as the "most interesting book that I have read on economics for years" (Adelman 2013, p. 350).
} 
models and an argument for the impact of capital accumulation on growth through the effects of investment on productivity (see also Boianovsky 2012).

Because of indivisibilities, a high minimum quantum of investment to start the development process required a high of volume of saving, difficult to attain in poor countries. The way out of this "vicious circle", according to Rosenstein-Rodan (1961a), was to have first an increase of income due to higher investment that activates potential resources, followed by a second stage when the marginal propensity to save is greater than the average one in conditions of growing income. The English Industrial Revolution had not been preceded by a fall in consumption; instead, the proportion of income saved from the increased income was higher than before. This is not far from Lewis's and Rostow's interpretations of the behavior of the saving ratio in that historical episode.

The main function of foreign capital inflow in developing countries was to increase the rate of domestic capital formation up to a level (Rosenstein-Rodan mentioned $12 \%$, the same figure used by Lewis and Rostow), after which each country would move to self-sustained growth as the domestic marginal saving rate increased with higher income (Rosenstein-Rodan 1961b, p. 107). The formula deployed by Rosenstein-Rodan (pp. 117, 135) to calculate capital requirements was a variation of the so-called Harrod-Domar equation. Its role was not to provide an explanation of why the Big Push was necessary, but to calculate capital inflow once the theoretical argument had been put forward. Accordingly, Rosenstein-Rodan did not refer to Harrod or Domar while deriving his arithmetical formula for foreign aid.

Doubts about the proper interpretation of the ICOR and of the relation between capital accumulation and growth started to pop up in the 1960s, after empirical estimates by Solow (1957) and others had indicated the relatively small contribution of capital to the economic growth of the US and other advanced economies. Harvey Leibenstein (1966), who had previously used the ICOR as a key instrument of development planning (Leibenstein 1957), carried out the first investigation of the short-run association between ICOR and growth. In his opening paragraph, Leibenstein (1966, p. 20) stated that

One of the attractive aspects of the Harrod-Domar model is the magnificent simplicity of its variables. This is especially true of the incremental capitaloutput ratio (ICOR). It has served as a magnet for economists (including the present writer). Many have been unable to resist employing it as a major 
element in their attempts to understand economic growth. But are ICORs really helpful in understanding growth? How are ICORs and growth rates really related?

The empirical findings - based on observations for 18 developed and underdeveloped countries - showed that the correlation was negative. This implied that the ICOR was really a function of growth instead of the other way around. Further implications included serious doubts about the usefulness of the accelerator as an analytical tool and of the capital-output ratio as a planning instrument (Leibenstein 1966, p. 24; see also Bruton 1965, p. 357; Patel 1968; Hagen 1968, pp. 187-88; Morgan 1969, pp. 398-99). ${ }^{13}$

Paul Streeten (1968) reached similar results in his detailed study of the methodological foundations of economic models in general and the Harrod-Domar model in particular (called "capital/output model"), and of its application to development planning. Streeten (pp. 1975-77) used several diagrams to indicate the difficulty of measuring ICOR and interpreting the relation between changes in capital and output when economic growth is dominated by autonomous technical progress. He concluded that ICOR could be used "neither to calculate investment requirements for given output increments nor to estimate additional output from given investment" (p. 1996). Such criticisms of the capital-output ratio model were put to rest until Easterly $(1999 ; 2001$, chapter 2) resumed them by investigating whether growth can be predicted with a constant ICOR. Easterly (2001, p. 295, n. 22) referred to Leibenstein (1966) and Patel (1968). Like those authors, he was interested in the short-run causality - since the long-run positive relation between investment and growth, as well as the long-run stability of the capital-output ratio in steady state, are not controversial - but adopted the slightly distinct test of regressing growth against lagged investment. Easterly's conclusions, that the ICOR is not an independent causal factor but just a ratio between two variables (investment and growth) loosely related, echoed the 1960s literature.

${ }^{13}$ Correlation tests between investment ratios and output growth were also run by Hamberg (1971, pp. 169-73) to assess what he called the Harrod-Domar Weltanschauung that a rise in the saving-investment ratio $s$ will permanently raise growth rates. Hamberg's tests did not disprove the null hypothesis of a zero rank correlation coefficient. 
Reflecting in part the increasing influence of the neoclassical growth model, development economists at the time gradually departed from what they perceived as the Harrod-Domar paradigm. Everett Hagen (1968, p. 175), a colleague of Solow and Domar at MIT, asserted that the problem of obtaining an increase in aggregate demand "is not a growth problem", and that development economics should instead focus on the increment of potential output. "We shall therefore give only briefly attention to the problem of demand; for example to the 'Harrod-Domar' problem of how an economy can be held at its capacity level of production as capacity increases". In the same vein, Henry Bruton (1965) - who had earlier pointed to the HarrodDomar analysis as the solution to the lack of formal modeling that seemed to beset development economics (Bruton 1955) - came to endorse the Solow-Swan model as the best apparatus to study economic development. Harrod and Domar, of course, were informed of the emerging development economics literature and considered how their respective theoretical frameworks could (or not) be applied to economic development.

\section{Harrod and Domar on economic development and capital}

In contrast with previous theories by classical economists, Marx, Keynes, Hansen and others, the Harrod-Domar models did not feature any necessary tendency to stagnation or the stationary state, which was only one of possible scenarios (see Backhouse and Boianovsky 2016). What attracted development economists to those models in the 1950s was precisely the idea of self-sustained growth through the reinvestment of part of the increased output through additional saving into additional investment at constant capital-output ratios with no exhaustion of investment opportunities, which notably distinguished them from previous approaches (Singer [1961] 1964, pp. 8-9; Furtado 1954, pp. 245-46). It is therefore ironic that Harrod (1948, pp. 19-20, 114; 1955a, p. 356; 1955b, pp. 336-39; 1973, pp. 24-26) - who assumed away in his dynamic economics the classical law of diminishing returns from land and Malthus's population doctrine - would suggest that "old classical analysis" applied better to vast "poverty-stricken areas of the world today", where population "is pressuring upon the means of subsistence" (1948, pp. 19 and 114). 
From that point of view, economic development of poor countries remained largely outside the terms of reference of Harrod's dynamics.

Nevertheless, probably as a reaction to the widespread use of his and Domar's equations by development planners, Harrod (1960; 1963a; 1963b) eventually discussed the application of his dynamic analysis (with exogenous population growth) to developing economies, which became an important topic of his agenda. ${ }^{14}$ Harrod (1963a, p. 421) declared in his presidential address to the Royal Economic Society that "many economists are finding, as I do, their attention attracted to the developing countries. That partly accounts for my continuing interest in growth economics”. In 1961 he organized for the International Economic Association a conference in Brissago (Switzerland) on trade and development (Harrod 1963c). In his turn, Domar (1957a, p. 5) remarked that, despite the fact that his 1940s models treated growth mainly as a remedy for unemployment, they "can be, and have been, adapted to deal with growth as an end in itself', as illustrated by the last (and only new) essay in his book, about Fel'dman's Soviet two-sector model of development planning (Domar 1957b).

It was clear to both Domar and Harrod that unemployment in developing countries was often not associated with insufficient effective demand or even with fixed coefficients. Domar (1953, pp. 562-63) doubted the possibility of substitution between factors could eliminate unemployment in poor economies, where the "marginal product of labor can be so low as not to warrant the expense and trouble of hiring and training additional workers, even at a starvation wage". Moreover, a member of a peasant household usually shared in family lodging and food and was therefore rewarded "in relation to the average, rather than his marginal, product". If he moved to urban industries, he would have to pay for lodging and food, but his wage could not surpass his marginal product, which must be higher than average product in agriculture. Hence, "he is apt to stay home and as a result the marginal

\footnotetext{
${ }^{14}$ Harrod (1968) was aware that his equations were mostly used in the literature in their tautological form. However, there are no records of complaint by him against the (mis)use or adaptation of his ideas by development economists. Others, like Swan (1964), did complain. According to Swan (p. 4), Harrod "has been concerned mainly with the short-run implications of a conflict between warranted and natural growth rates ... Unfortunately, others took him up and all over the world people began eagerly calculating the components of $G C=S$ without enquiring either what the symbols really meant or whether their statistics had any meaning in relation to symbols".
} 
product in agriculture can be very close to zero, or [if population increases] even below zero. Is this not unemployment, whatever production function the economist prefers to use?"

Domar's remarks were close to Lewis's dual economy model that would come out the year after, but without Lewis's mechanism of labor transfer to "modern" capitalist industry and ensuing increase of profit share caused by the difference between the marginal product in industry and agriculture. Harrod (1957a, 1959b) too distinguished disguised unemployment from Keynesian involuntary unemployment.

There is not a reserve of labor which could be brought to work in producing useful consumer goods if only demand were there. Much of the underemployed labor may be attached to agriculture, where the marginal physical productivity is more or less zero, so that the extra demand would not increase output. (Harrod 1959b, p. 104)

The Keynesian multiplier does not operate in that case (Harrod 1957a, pp. 10-11; cf. Rao [1952] 1958 and Sunkel 1957). Domar (1953, pp. 561-62) probably had those circumstances in mind when he suggested that a higher propensity to save would be beneficial to underdeveloped countries (especially in Southeast Asia) characterized by an increase of capital at lower rates than population -- "provided it does result in useful investment and is not dissipated in still larger unemployment ... and the usefulness of capital is not inhibited by the absence of a properly trained labor force and other required inputs".

Domar and Harrod did not assume perfectly elastic labor supply à la Lewis in their respective growth analyses. This is explicit in Harrod's concept of the natural growth rate $G_{n}$ as a ceiling and implicit in Domar's ([1946] 1957a, pp. 73-74) discussion of the effects of labor scarcity on the productivity of capital. Harrod (1960, 1963a,b) introduced the notion of "optimum rate of savings" $s_{r}=C_{r} G_{n}$ as the propensity to save required to implement the maximum growth of production so that the natural and warranted rates are equal. As explained by Harrod, $s_{r}$ is a dependent variable, unlike the saving ratio $s$ in the formula for the warranted or required growth rate (see Boianovsky 2017a).

Domar ([1947a] 1957a, p. 97) had suggested a similar expression as a variant of his equation $r=\alpha \sigma$, which determined the required equilibrium growth rate for 
given $\alpha$ and $\sigma$. That equation could be solved for $\alpha$ (in terms of $r$ and $\sigma$ ) and for $\sigma$ (in terms of $r$ and $\alpha$ ), assuming that $r$ was given, "for instance by technological progress". Hence, $\alpha=r / \sigma$ was the propensity to save required to bring the economy to its full employment growth path. ${ }^{15}$ Harrod's and Domar's equations for $s_{r}$ and $\alpha$, with the propensity to save treated as a dependent variable, may look similar to development economists' expression for capital requirements. However, instead of aiming at a certain target growth rate under perfectly elastic labor supply as in the development planning literature, Domar and (particularly) Harrod investigated the saving ratio consistent with the full employment growth path decided by population growth and technical progress. ${ }^{16}$

According to Harrod, developing countries suffered from insufficiency of saving to "finance natural growth". However, one should be careful about this, as slow growth in those countries was often due not to a low saving ratio per se, but to "the difficulty of building up an increase of technological know-how and of personnel well qualified to implement it" (Harrod 1973, p. 108). In his review of Kurihara's (1956) Keynesian Dynamics, Harrod (1957b, p. 193) criticized the view that the major problem facing underdeveloped economies was "increasing capital accumulation" (Kurihara, p. 211). "Is this not a wrong emphasis, not confined to Professor Kurihara?" asked Harrod. More important limitations came from factors deciding the natural rate of growth of per capita output. Harrod's (1963b, p. 114) “dynamized version of the law of diminishing returns" asserted that the rate at which future income can be raised by saving depends on the availability of factors other than capital (labor and natural resources). In general, any attempt to accumulate capital considerably faster than the other factors "will add little to the rate of growth of

\footnotetext{
15 Domar also wrote the equation in the alternative form $\sigma=r / \alpha$. With this closure, the capital-output ratio becomes the dependent variable, just as in Solow's (1956) and Swan's (1956) formulations. The choice of how to close the model depended on the kind of problem addressed (see Boianovsky 2017b).

16 Planning for full employment - implicitly assumed as unreachable - was exceptional among developing countries (Little 1982, p. 42). The United Nations (1960, p. 13) document drafted by Tinbergen considered in passing setting the rate of growth so as to achieve full employment, which corresponded to the sum of demographic growth and labor productivity increase.
} 
income" (ibid). This was related to the notion of "absorptive capacity" mentioned above (see Guillamount 1971, pp. 55-57).

Diminishing returns to capital - based on the substitution between capital and other production factors - were an important aspect of Harrod's approach to economic development, despite the fact that he did not deploy an aggregate production function (or total amount of outstanding capital) in his "fundamental equations" (Maclachlan 2016; Harrod 1939, p. 16; 1959, p. 453). In his review of Production of commodities by means of commodities, Harrod (1961) rejected Sraffa's demonstration of double-switching and capital-reversal phenomena in capital theory, and defended instead the traditional notion of the production period (capital-output ratio) as an inverse function of the rate of interest. Sraffa (1962) held his ground, in what was his last publication.

Planning in developing countries was not mainly about reaching the natural growth rate, but changing the natural path itself. The main determinant of Harrod's $G_{n}$ in developing countries was the maximum rate at which qualified personnel could be increased and bring (mostly) imported technology to use. The supplement to entrepreneurship through planning may raise that rate and thereby cause an upward shift in the natural growth curve, accompanied by a higher $s_{r}$. If actual growth is below natural growth only because of the shortage of saving, there are available qualified personnel to implement the new technology. In these circumstances, to obtain "social optimum" it is necessary to raise $s$ towards $s_{r}$ by fiscal policy, bringing the economy to a "transitional period" in which actual growth is above the natural rate, owing to the exploiting of previously underemployed skilled workers. Once the limited fund of such personnel is taken up, transitional growth is merged into regular natural growth. Hence, there are clear limits to the effect of higher saving on the rate of growth, since its "very essence ... is the education by practice and the gradual drawing out of the latent potentialities of personnel" (1960, p. 291).

It is important to avoid over-simplified ideas about the consequences of the mere provision of additional saving. This view might be regarded as pessimistic in that it sets a limit to what can be done by one simple recipe (more saving); but it is optimistic in that it enables us to curb the impulses of 
those who believe Utopia can be gained solely by the imposition of harsh austerity (ibid). ${ }^{17}$

This may be read as a critical reaction to the way his equations were used by some development planners at the time.

Like Harrod, Domar pointed to skilled labor, instead of physical capital, as the main determinant of economic development. He saw development as a "difficult and complex process, hard to deal with, because contrary to some of our favorite models, it is essentially not a capital but a human problem" (Domar 1966, p. 10). Domar ([1944] 1957a, p. 59) had ascribed American economic growth in the period 18791928 to technological improvement and increase of the labor force, which corresponded to Harrod's (1948) "fundamental conditions" behind the natural growth rate. Domar, however, did not articulate that with the aggregate demand part of his model, as he lacked Harrod's $G_{n}$ concept.

Domar (1955, p. 250) was critical of neoclassical economics for its emphasis on the elasticity of substitution between factors and products and overall concern with the static combination of factors of production as determined by relative prices. If "capital and labor were easily and freely substitutable for each other, their respective relations to output could hardly have much significance" (ibid). The traditional notion of continuous cost curves had led in practice to the exclusion of the concept of capacity and its relation to output, central to Domar's framework. He was enthusiastic about W. Leontief's linear input-output system, which, instead of the "pet theoretical toys" of marginal analysis, employed allegedly constant coefficients "not visibly derived from profit maximization" (Domar [1952] 1957a, p. 29). In fact, the virtue of Leontief's system, according to Domar (ibid), was its ability to get good results without using such concepts and thus show them "their proper place as servants to be called in if and when required".

In his formal restatement of Fel'dman's ([1928] 1964) Marxian two-sector growth model, Domar (1957b, p. 244) noticed two assumptions that distinguished it from his own formulation: unlimited supply of labor and absence of cyclical

17 The optimum flow of international lending should be such as to prevent capital from restricting economic growth, given the rates of growth of non-capital factors. Increasing domestic saving via the reduction of consumption could have perverse incentive effects on labor supply by skilled workers, which was also behind Harrod's $(1960,1963 b)$ case for foreign aid. 
disturbances or effective demand problems. The new element contained in Fel'dman's model was the hypothesis that the crucial restriction to growth is represented not by saving but by the capacity to produce capital goods - otherwise saving cannot be translated into an increase in investment. ${ }^{18}$ One of Domar's (1957a) main contributions to development planning was the determination of the optimal distribution of capital goods between the consumption and investment sectors of the economy according to different goals. In particular, Domar established that an increase in the proportion of capital goods allocated to producing more capital goods eventually brings about a higher permanent level of consumption (see also Boianovsky 2017d). This is known as the "Fel'dman-Domar-Mahalanobis model", because of related contributions made by Mahalanobis in the context of Indian economic planning in the 1950s (Findlay 1966; Jones 1975, sections 5.6 and 5.7). It led to a strategy of economic development based on heavy industries and high capitallabor ratios. ${ }^{19}$

Despite his praise for Fel'dman's model, Domar (1957b, pp. 256-57) was critical of its straightforward application to planning by playing with the values of parameters. Russian development planners had failed to realize that those parameters (especially the capital coefficients) were "mere abstractions", useful in theoretical work, but dangerous in practical applications because of what they concealed about the actual working of the economy. The "problem of economic development" did not lie in "algebraic manipulations" à la Fel'dman but in overcoming the "administrative, technological and human obstacles that a rapid industrialization of a backward peasant economy was bound to create" - of course, that was difficult to put in a model. Domar (1957a, p. 13) extended that piece of criticism to the widespread belief by development planners that, by assuming plausible values for the saving ratio and the capital coefficients, "economic development seems assured". ${ }^{20}$

\footnotetext{
${ }^{18}$ As pointed out by Abramovitz (1952, pp. 155-56), Keynes's concept of the marginal efficiency of capital as a function of the cost of producing capital goods implied that the level of capital formation a country can attain depends on the capacity of the capital goods sector.

${ }^{19}$ Harrod (1963a, p. 412; 1966) argued that development planners should attempt to maximize capital productivity (i.e. low capital-output ratio), which he distinguished from minimizing capital intensity (i.e. low capital-labor ratio). In fact, there was no direct relation between those two ratios, he claimed.

${ }^{20}$ See also Lowe (1955) on the "construction period" of capital goods and on the importance of incentives as opposed to a purely physical-technical view on
} 
When exposed, at the 1958 Corfu conference on capital, to the Solow-Swan result that, due to diminishing returns to capital, the permanent rate of economic growth is independent of the propensity to save, Domar found it "striking". But, in his view, it did not prevent "economists from developed countries from pressing upon their colleagues in less-developed countries the standard question about the fraction of output which the less-developed countries invested" (Lutz and Hague 1961, report on the proceedings, p. 394). The debate that followed Domar's remarks, involving P.A. Samuelson, N. Kaldor, D.G. Champernowne and R. Solow, brought out the distinction between rates and level effects of changes in the propensity to save. Domar closed the debate by suggesting that "so long as technological progress was ruled out when investment took place, capital accumulation was not important to growth in the long run". Unlike Harrod, Domar usually assumed embodied technical progress.

The interpretation of the observed long-run stability of the capital-output ratio attracted Domar's attention. Domar's $(1955,1961)$ calculations of the American capital-output ratio confirmed its relative stability over time. Anticipating some of the causality issues discussed by development economists in the 1960s and later, Domar warned about the meaning of such stability.

This does not necessarily presuppose any specific causal relationship between these three variables. It is possible that the capital coefficient and the fraction of output invested have yielded a certain rate of growth of output. But it is also possible that other factors besides capital have been mainly responsible for the existing rate of growth of output, and the given capital coefficient has simply resulted from the interaction of the other variables. Thus the relative stability of the capital coefficient is not a sufficient indication of the role of capital formation in economic growth (Domar 1961, p. 103).

The matter was largely empirical. In view of the findings about the contribution of technical progress to growth, the capital coefficient "will emerge as a relatively passive result of the interaction between the propensity to save and the rate of technological progress" (ibid, p. 117). This corresponds to Domar's third closure $\sigma=$

production. Lowe's structural approach is reminiscent (but independent) of Fel'dman's, and influenced Dobb's three-sector model (see Hagemann and Jeck 1984). 
$r / \alpha$ mentioned above. Clearly, the description of Harrod and Domar as supporters or creators of "capital fundamentalism" is a simplification that hides more than it reveals in the complex history of development economics.

Most development economists in the 1950s and 1960s were aware that Harrod's and Domar's growth models addressed economic instability issues, not longrun growth. They reacted by adapting the model(s) to their own purposes (as illustrated by development planners), by pointing out the models' limitation in the interpretation of economic development (Lewis, Rostow, Hirschman, Sunkel), and by questioning the causal empirical relation between ICOR and economic growth (Leibenstein, Streeten, and, more recently, Easterly). The relative complexity of Domar's and (especially) Harrod's formulations is also evident from interpretations put forward by growth economists (Solow, Robinson, Fellner), which diverged from the original views of the authors. When Harrod and Domar came to tackle long-term economic development in the 1960s, they pointed to factors other than capital accumulation as its key determinants. However, by then the growth model(s) they had invented between the late 1930s and late 1940s had already a life of its own, largely independent of its original creators.

Acknowledgements. I would like to thank Geoff Harcourt, Deirdre McCloskey, Tony Thirlwall, Kevin Hoover, Roy Weintraub, Bruce Caldwell, Clara Mattei and three anonymous referees for helpful comments on earlier drafts. I've benefited from a research grant from Capes (Brazil). Permission to quote from the Domar Papers (Economists' Papers Project, David M. Rubenstein Rare Book and Manuscript Library, Duke University) is gratefully acknowledged.

\section{References}

Abramovitz, M. 1952. Economics of growth. In B.F. Haley (ed), pp. 132-78.

Adelman, J. 2013. Wordly philosopher: the odyssey of Albert O. Hirschman. Princeton (NJ): Princeton University Press.

Agarwala, A. and S. Singh (eds). 1958. The Economics of Underdevelopment. London: Oxford University Press. 
Aghion, P. and P. Howitt. 1998. Endogenous growth theory. Cambridge (Mass): MIT Press.

Arndt, H. 1987. Economic Development - The History of an Idea. Chicago: Chicago University Press.

Barro, R. and X. Sala-i-Martin. 1995. Economic growth. New York: McGraw-Hill.

Backhouse, R.E. and M. Boianovsky. 2016. Secular stagnation: the history of a macroeconomic heresy. European Journal of the History of Economic Thought. 23: 946-70.

Besomi, D. 2001. Harrod's dynamics and the theory of growth: the story of a mistaken attribution. Cambridge Journal of Economics. 25: 79-96.

Boianovsky, M. 2010. A view from the tropics: Celso Furtado and the theory of economic development in the 1950s. History of Political Economy. 42: 221-66.

Boianovsky, M. 2012. Svennilson and the Kaldor-Verdoorn Law. In Macroeconomics and the history of economic thought: Festschrift in honour of Harald Hagemann, chapter 8. Edited by H. M. Krämer, H.D. Kurz and H.-M. Trautwein. London: Routledge.

Boianovsky, M. 2017a. Optimum saving and growth: Harrod on dynamic welfare economics. Oxford Economic Papers. 69 (forthcoming). Available online 15 February 2017.

Boianovsky, M. 2017b. Modeling economic growth: Domar on moving equilibrium. History of Political Economy. 49 (forthcoming).

Boianovsky, M. 2017c. When the history of ideas meets theory: Arthur Lewis and the classical economists on development. Unpublished typescript.

Boianovsky, M._2017d. Domar, underconsumption and the Marxian reproduction schemes. Unpublished typescript.

Boianovsky, M. and K.D. Hoover. 2009a. The neoclassical growth model and twentieth-century economics. In Boianovsky and Hoover 2009b, pp. 1-23.

Boianovsky, M. and K.D. Hoover (eds). 2009b. Robert Solow and the development of growth economics. Annual supplement to vol. 41 of History of Political Economy. Durham: Duke University Press. 
Boianovsky, M. and R. Solís. 2014. The origins and development of the Latin American structuralist approach to the balance of payments, 1944-1964. Review of Political Economy. 26: 23-59.

Brems, H. 1968. Quantitative economic theory: a synthetic approach. New York: John Wiley \& Sons.

Bruton, H.J. 1955. Growth models and underdeveloped economies. Journal of Political Economy. 63: 322-36.

Bruton, H.J. 1965. Principles of development economics. Englewood Cliffs (NJ): Prentice-Hall.

Cesaratto, S. 1999. Saving and economic growth in neoclassical theory. Cambridge Journal of Economics. 23: 771-93.

Cesaratto, S. 2015. Neo-Kaleckian and Sraffian controversies on the theory of accumulation. Review of Political Economy. 27: 154-82.

Chenery, H.B. and M. Bruno. 1962. Development alternatives in an open economy: the case of Israel. Economic Journal. 72: 79-103.

Chenery, H.B. and A.M. Strout. 1966. Foreign assistance and economic development. American Economic Review. 56: 679-733.

Domar, E. [1946] 1957a. Capital expansion, rate of growth, and employment. Econometrica. 14: 137-47. As reproduced in Domar (1957a), pp. 70-82.

Domar, E. [1947] 1957a. Expansion and employment. American Economic Review. 37: 34-55. As reproduced in Domar (1957a), pp. 83-108.

Domar, E. 1948a. Investment, losses, and monopolies. In Income, employment and public policy - essays in honor of Alvin H. Hansen, pp. 33-53. New York: Norton.

Domar, E. [1948b] 1957. The problem of capital accumulation. American Economic Review. 38: 777-94. In Domar (1957a), pp. 109-28.

Domar, E. [1952] 1957aa. Economic growth: an econometric approach. American Economic Review. 42: 479-95. Reproduced as "A theoretical analysis of economic growth" in Domar (1957a), pp. 16-34.

Domar, E. 1953. Further comment. Quarterly Journal of Economics. 67: 559-63.

Domar, E. 1955. The inter-relation between capital and output in the American economy. In Dupriez (ed), pp. 249-69. 
Domar, E. 1957a. Essays in the theory of economic growth. New York: Oxford University Press.

Domar, E. 1957b. A Soviet model of growth. In Domar (1957a), pp. 223-61.

Domar, E. 1957c. Contributions of federal expenditure to economic growth and stability. In Federal expenditure policy for economic growth and stability, pp. 267-84. Joint Economic Committee. Washington: Government Printing Office.

Domar, E. 1961. The capital-output ratio in the United States: its variation and stability. In Lutz and Hague (eds), pp. 95-117.

Domar, E. 1966. John R. Commons Lecture: Reflections on economic development. The American Economist. 10: 5-13.

Domar, E. 1967. The theory of economic growth: its present state. Lecture delivered at the Economic Development Institute. Domar Papers, Box 9, Economists' Papers Project, David M. Rubenstein Rare Book and Manuscript Library, Duke University.

Dupriez, L.H. (ed) 1955. Economic progress. Louvain: Institut de Recherches Economiques et Sociales, for the International Economic Association.

Easterly, W. 1999. The ghost of financing gap: testing the growth model used in international financial institutions. Journal of Development Economics. 60: 423-38.

Easterly, W. 2001. The elusive quest for growth. Cambridge (MA): MIT Press.

Enke, S. 1963. Economics for development. Englewood Cliffs (N.J.): Prentice-Hall.

Fel'dman, A.G. [1928] 1964. On the theory of growth rates of national income. Translated in Foundations of Soviet strategy for economic growth, pp. 174-99 and 304-31, ed. by N. Spulber. Bloomington (IN): Indiana University Press.

Fellner, W. 1951. The capital-output ratio in dynamic economies. In Money, trade and economic growth - In honor of John Henry Williams, pp. 105-34. New York: Macmillan.

Fellner, W. 1954. Long term tendencies in private capital formation - the rate of growth and capital coefficients. In Long-range economic projection, pp. 273332. Conference on Research on Income and Wealth. New York: NBER.

Findlay, R. 1966. Optimal investment allocation between consumer goods and capital goods. 76: 70-83.

Fish, S. 1980. Is there a text in this class? Cambridge (Mass): Harvard University Press. 
Furtado, C. 1954. A Economia Brasileira (The Brazilian Economy). Rio: A Noite.

Gollin, D. 2014. The Lewis model - a 60-year retrospective. Journal of Economic Perspectives.28: 71-88.

Guillaumont, P. 1971. L'absorption du capital. Paris: Éditions Cujas.

Hagemann, H. and A. Jeck. 1984. Lowe and the Marx-Fel'dman-Dobb model: structural analysis of a growing economy. Eastern Economic Journal. 10: 169-86.

Hagen, E.E. 1968. The economics of development. Homewood (IL): Richard D. Irwin.

Hahn, F.H. and R.C.O. Matthews. 1964. The theory of economic growth: a survey. Economic Journal. 74: 779-902.

Haley, B.F. (ed). 1952. A survey of contemporary economics, vol. II. Homewood (Ill): Richard D. Irwin for the American Economic Association.

Halsmayer,V. and K.D. Hoover. 2015. Solow's Harrod: transforming macroeconomic dynamics into a model of long-run growth. European Journal of the History of Economic Thought. 23: 561-96.

Hamberg, D. 1956. Economic growth and instability. New York: Norton.

Hamberg, D. 1971. Models of economic growth. New York: Harper \& Row.

Hansen, A.H. 1941. Fiscal policy and business cycles. New York: Norton.

Harcourt, G.C. 2006a. The structure of post-Keynesian economics. Cambridge: Cambridge University Press.

Harcourt, G.C. 2006b. The Harrod model of growth and some early reactions to it. In The Elgar companion to development studies, pp. 219-23, ed. by D.A. Clark. Cheltenham: E. Elgar.

Harrod, R.F. 1936. The trade cycle: an essay. Oxford: Oxford University Press.

Harrod, R. F. 1939. An essay in dynamic theory. Economic Journal. 49: 14-33.

Harrod, R. F. 1948. Towards a Dynamic Economics. London: Macmillan.

Harrod, R. F. 1955a. Les relations entre l'investissement et la population. Revue Économique. 6: 356-67.

Harrod, R.F. 1955b. Assisting underdeveloped regions. Confluence. 4: 335-46. 
Harrod, R. F. 1957a. Professor Fellner on growth and unemployment. Kyklos. 10: 115.

Harrod, R. F. 1957b. Review of Kurihara 1956. Annals of the American Academy of Political and Social Sciences. 313: 192-94.

Harrod, R. F. 1959a. Domar and dynamic economics. Economic Journal. 69: 451-64.

Harrod, R. F. 1959b. Inflation and investment in underdeveloped countries. In Ekonomi Politik Samhälle - en bok tillägnad Bertil Ohlin på sextio-årsdagen. Stockholm: Bokförlaget Folk och Samhälle.

Harrod, R. F. 1960. Second essay in dynamic theory. Economic Journal. 70: 277-93.

Harrod, R.F. 1961. Review of Sraffa (1960). Economic Journal. 71: 783-87.

Harrod, R. F. 1962. Economic development and Asian regional cooperation. Pakistan Development Review. 2: 1-22.

Harrod, R.F. 1963a. Themes in dynamic theory. Economic Journal. 73: 401-21.

Harrod, R. F. 1963b. Desirable international movements of capital in relation to growth of borrowers and lenders and growth of markets. In Harrod (1963c), pp. 113-41.

Harrod, R.F. (ed). 1963c. International trade theory in a developing world. London: Macmillan, for the International Economic Association.

Harrod, R. F. 1966. Optimum investment for growth. In Problems of economic dynamics and planning: essays in honor of Michal Kalecki, pp. 169-79. Oxford: Pergamon Press.

Harrod, R. F. 1973. Economic dynamics. London: Macmillan.

Higgins, B. 1959. Economic development-principles, problems and policies. New York: Norton.

Hirschman, A. 1958. The strategy of economic development. New Haven: Yale University Press.

Jones, H.G. 1975. An introduction to modern theories of economic growth. London: Nelson.

Kaldor, N. 1961. Capital accumulation and economic growth. In Lutz and Hague (eds), pp. 177-222.

Kaldor, N. 1966. Causes of the slow rate of economic growth in the United Kingdom. Cambridge: Cambridge University Press.

Keynes, J.M. 1937. Some economic consequences of a declining population. 
Eugenics Review. 29: 13-17.

King, R.G and R. Levine. 1994. Capital fundamentalism, economic development, and economic growth. Policy Research Working Paper \# 1285. World Bank, Policy Research Department.

Kregel, J. 1980. Economic dynamics and the theory of steady growth: an historical essay on Harrod's 'knife-edge'. History of Political Economy. 12: 97-123.

Kriesler, P. 2013. Post-Keynesian perspectives on economic development and growth. In The Oxford Handbook of Post-Keynesian Economics, pp. 539-55, ed. by G.C. Harcourt and P. Kriesler. Oxford: Oxford University Press.

Kurihara, K. 1956. Introduction to Keynesian dynamics. New York: Columbia University Press.

Kurihara, K. 1959. The Keynesian theory of economic development. London: Allen \& Unwin.

Leibenstein, H. 1957. Economic backwardness and economic growth. New York: John Wiley \& Sons.

Leibenstein, H. 1966. Incremental capital-output ratios and growth rates in the short run. Review of Economics and Statistics. 48: 20-27.

Lewis, W. A. 1954. Economic development with unlimited supplies of labor. Manchester School. 22: 139-91.

Lewis, W. A. 1955. Theory of Economic Growth. London: Allen \& Unwin.

Little, I. 1982. Economic Development - Theory, Policy and International Relations. New York: Basic Books.

Lowe, A. 1955. Structural analysis of real capital formation. In Capital formation and economic growth, ed. by M. Abramowitz, pp. 579-632. New York: NBER

Lutz, F.A. and D.C. Hague (eds.) 1961. The Theory of Capital. London: Macmillan.

McCloskey, D.N. 2010. Bourgeois dignity - why economics can't explain the modern world. Chicago and London: University of Chicago Press.

Maclachlan, F. 2016. Harrod and the Cambridge Keynesians. Paper presented at the conference " 40 years of the Cambridge Journal of Economics".

Mahalanobis, P.C. 1953. Some observations on the process of growth of national income. Sankhya. 12: 307-12.

Mahalanobis, P.C. 1955. The approach of operational research to planning in India. Sankhya. 16: 3-130. 
Marglin, S.A. 1984. Growth, distribution, and prices. Cambridge (Mass.): Harvard University Press.

Meier, G.M. and R.E. Baldwin. 1957. Economic development - theory, history, policy. New York: John Wiley \& Sons.

Meier, G. M. 2005. Biography of a subject - an evolution of development economics. Oxford: Oxford University Press.

Morgan, T. 1969. Investment versus economic growth. Economic Development and Cultural Change. 17: 392-414.

Myrdal, G. 1968. Asian Drama - An inquiry into the poverty of nations. New York: Pantheon.

Nurkse, R. 1953. Problems of Capital Formation in Underdeveloped Countries. Oxford: Blackwell.

Patel, S.J. 1968. A note on the incremental capital-output ratio and rates of economic growth in the developing countries. Kyklos. 21: 147-50.

Perez Caldentey, E. and M. Vernengo. 2016. Reading Keynes in Buenos Aires: Prebisch and the dynamics of capitalism. Cambridge Journal of Economics. 40: 1725-41.

Prebisch, R. 1948. La crisis de la economia política y la revolución Keynesiana. Unpublished typescript. Archivo de Trabajo de Raul Prebisch, caja 3. CEPAL Library, Santiago.

Prebisch, R. 1954. The relationship between population growth, capital formation and employment opportunities in under-developed countries. Proceedings of the World Population Conference 1954, pp. 695-711. Rome 31 August - 10 September. New York: United Nations. E/CONF.13/417.

Rao, V.K.R.V. [1952]. 1958. Investment, income and the multiplier in an underdeveloped economy. In Agarwala and Singh (eds), pp. 2015-18. Originally published in Indian Economic Review 1: 55-67.

Ray, D. 1998. Development economics. Princeton (NJ): Princeton University Press.

Robinson, J. 1949. Mr. Harrod's dynamics. Economic Journal. 59: 68-85.

Robinson, J. 1956. The accumulation of capital. London: Macmillan.

Robinson, J. 1962. Economic philosophy. Middlesex: Penguin.

Rosenstein-Rodan, P. 1943. Problems of industrialization of Eastern and Southeastern Europe. Economic Journal. 53: 202-11. 
Rosenstein-Rodan, P. 1961a. Notes on the theory of the "big push". In H. Ellis and H. C. Wallich (eds), Economic Development for Latin America, pp. 57-67. London: Macmillan, for the International Economic Association.

Rosenstein-Rodan, P. 1961b. International aid for underdeveloped countries. Review of Economics and Statistics. 43: 107-38.

Rostow, W. 1952. The Process of Economic Growth. New York: Norton.

Rostow, W.W. 1955. Some general reflections on capital formation and economic growth. In Capital formation and economic growth, pp. 635-67, ed. by $\mathrm{M}$. Abramovitz. Princeton: Princeton University Press and NBER.

Rostow, W.W. 1956. The take-off into self-sustained growth. Economic Journal. 66: $25-48$.

Rostow, W. 1960. The Stages of Economic Growth. Cambridge: Cambridge University Press.

Rostow, W.W. 1971. The Stages of Economic Growth, $2^{\text {nd }}$ edition. Cambridge: Cambridge University Press.

Sen, A. 1983. Development: which way now? Economic Journal. 93: 745-62.

Singer, H. W. [1952] 1958. The mechanics of economic development: a quantitative model approach. In Agarwala and Singh (eds), pp. 381-99. Originally published in Indian Economic Review 2: 1-18.

Singer, H. W. 1954. Population and economic development. Proceedings of the World Population Conference 1954, pp. 737-59. Rome 31 August - 10 September. New York: United Nations. E/CONF.13/417.

Singer, H.W. [1961] 1964. Recent trends in economic thought on underdeveloped countries. In Singer (1964), pp. 3-17.

Singer, H.W. 1964. International development: growth and change. New York: McGraw-Hill.

Snyder, C. 1936. The capital supply and national well-being. American Economic Review. 26: 195-244.

Snyder, C. 1940. Capitalism the creator. New York: Macmillan.

Solow, R.M. 1956. A contribution to the theory of economic growth. Quarterly Journal of Economics. 70: 65-94.

Solow, R.M. 1957. Technical change and the aggregate production function. Review of Economics and Statistics. 39: 748-62. 
Solow, R.M. 19to. Growth theory - an exposition. New York: Oxford University Press.

Solow, R.M. 1999, Neoclassical growth theory. In Handbook of macroeconomics, vol. 1, pp. 637-67, ed. by J.B. Taylor and M. Woodford. Amsterdam: Elsevier.

Sraffa, P. 1960. Production of commodities by means of commodities. Cambridge: Cambridge University Press.

Sraffa, P. 1962. Production of commodities: a comment. Economic Journal. 72: 47779.

Stern, E.H. 1945. Capital requirements in progressive economies. Economica. 12: 163-71.

Stern, N. 1991. The determinants of growth. Economic Journal. 101: 122-33.

Streeten, P. 1968. Economic models and their usefulness for planning in South Asia. Appendix 3 in Myrdal (1968), vol. 3, pp. 1941-2004.

Sunkel, O. 1956. El modelo de crecimiento de Domar [Domar's growth model]. El Trimestre Económico. 23: 201-17.

Sunkel, O. 1957. Cuál es la utilidad práctica de la teoría del multiplicador? [What is the practical use of the multiplier?]. El Trimestre Económico. 24: 251-75.

Sunkel, O. (with the assistance of P. Paz). 1970. El subdesarrollo latinoamericano $y$ la teoría del desarrollo. Mexico City: Siglo Ventiuno.

Swan, T.W. 1956. Economic growth and capital accumulation. Economic Record. 32: 334-61.

Swan, T.W. 1964. Growth models: of golden ages and production functions. In Economic development with special reference to East Asia, pp. 3-16, ed. by K. Berrill. New York: St. Martin's Press.

Thirlwall, A.P. 1987. Keynes, economic development and the developing countries. In Keynes and economic development - The seventh Keynes seminar at the University of Kent at Canterbury, 1985, pp. 3-35, ed. by A.P. Thirwall. London: Macmillan. 
Tignor, R. 2006. W. Arthur Lewis and the Birth of Development Economics. Princeton: Princeton University Press.

Tinbergen, J. 1958. The design of development. Washington (DC): The Economic Development Institute and the International Bank for Reconstruction and Development.

Tinbergen, J. 1987. The ET interview: Professor J. Tinbergen. Econometric Theory. 3: 117-42. Interviewed by J.R. Magnus and M.S. Morgan.

United Nations. Economic Commission for Latin America. 1955. Analyses and projections of economic development. I. An introduction to the technique of programming. E/CN.12/363. New York.

United Nations. Economic Commission for Latin America. 1956. Analyses and Projections of Economic Development - II. The Economic Development of Brazil. E/CN.12/364. New York.

United Nations. Economic Commission for Asia and the Far East. 1960. Programming techniques for economic development. E/CN.11/535. Bangkok.

Wan, H. Y., Jr. 1971. Economic growth. New York: Harcourt Brace Jovanovich.

Yotopoulos, P.A. and J.B. Nugent. 1976. Economics of development - empirical investigations. New York: Harper \& Row. 